\title{
Correction of severe spinopelvic mismatch: decreased blood loss with lateral hyperlordotic interbody grafts as compared with pedicle subtraction osteotomy
}

\author{
Jean-Christophe Leveque, MD, ${ }^{1}$ Vijay Yanamadala, MD, MBA, ${ }^{1}$ Quinlan D. Buchlak, MPsych, ${ }^{1}$ and \\ Rajiv K. Sethi, MD ${ }^{1,2}$
}

${ }^{1}$ Neuroscience Institute, Virginia Mason Medical Center; and ${ }^{2}$ Department of Health Services, University of Washington, Seattle, Washington

\begin{abstract}
OBJECTIVE Pedicle subtraction osteotomy (PSO) provides extensive correction in patients with fixed sagittal plane imbalance but is associated with high estimated blood loss (EBL). Anterior column realignment (ACR) with lateral graft placement and sectioning of the anterior longitudinal ligament allows restoration of lumbar lordosis (LL). The authors compare peri- and postoperative measures in 2 groups of patients undergoing correction of a sagittal plane imbalance, either through PSO or the use of lateral lumbar fusion and ACR with hyperlordotic $\left(20^{\circ}-30^{\circ}\right)$ interbody cages, with stabilization through standard posterior instrumentation in all cases.
\end{abstract}

METHODS The authors performed a retrospective chart review of cases involving a lumbar PSO or lateral lumbar interbody fusion and ACR (LLIF-ACR) between 2010 and 2015 at the authors' institution. Patients who had a PSO in the setting of a preexisting fusion that spanned more than 4 levels were excluded. Demographic characteristics, spinopelvic parameters, EBL, operative time, and LOS were analyzed and compared between patients treated with PSO and those treated with LLIF-ACR.

RESULTS The PSO group included 14 patients and the LLIF-ACR group included 13 patients. The mean follow-up was 13 months in the LLIF-ACR group and 26 months in the PSO group. The mean EBL was significantly lower in the LLIF-ACR group, measuring approximately $50 \%$ of the mean EBL in the PSO group (1466 vs $2910 \mathrm{ml}, \mathrm{p}<0.01$ ). Total LL correction was equivalent between the 2 groups $\left(35^{\circ}\right.$ in the PSO group, $31^{\circ}$ in the LLIF-ACR group, $p>0.05$ ), as was the preoperative PI-LL mismatch $\left(33^{\circ}\right.$ in each group, $\left.p>0.05\right)$ and the postoperative $\mathrm{PI}-\mathrm{LL}$ mismatch $\left(<1^{\circ}\right.$ in each group, $p$ $=0.05)$. The fusion rate as assessed by the need for reoperation due to pseudarthrosis was lower in the LLIF-ACR group but not significantly so ( 3 revisions in the PSO group due to pseudarthrosis vs 0 in the LLIF-ACR group, $p>0.5$ ). The total operative time and LOS were not significantly different in the 2 groups.

CONCLUSIONS This is the first direct comparison of the LLIF-ACR technique with the PSO in adult spinal deformity correction. The study demonstrates that the LLIF-ACR provides equivalent deformity correction with significantly reduced blood loss in patients with a previously unfused spine compared with the PSO. This technique provides a powerful means to avoid PSO in selected patients who require spinal deformity correction.

https://thejns.org/doi/abs/10.3171/2017.5.FOCUS17195

KEY WORDS pedicle subtraction osteotomy; adult deformity; minimally invasive surgery; lateral interbody; estimated blood loss

$\mathrm{S}$ AGITTAL imbalance is the primary predictor of disability in adult spinal deformity (ASD), and restoration of sagittal alignment and creation of spinopelvic harmony with matched pelvic incidence (PI) and lumbar lordosis (LL) is known to lead to the best long- term outcomes in ASD patients who undergo surgical correction. $4,18,33,34,63-65$ The traditional surgical approach for lordosis restoration in patients with severe spinopelvic mismatch has involved the use of the 3-column pedicle subtraction osteotomy (PSO). ${ }^{9,12,18,19,21,76}$ While

ABBREVIATIONS ACR = anterior column realignment; ALIF = anterior lumbar interbody fusion; $A L L=$ anterior longitudinal ligament; $A S D=$ adult spinal deformity; BMP = bone morphogenetic protein; EBL = estimated blood loss; LL = lumbar lordosis; LLIF = lateral lumbar interbody fusion; LOS = length of stay; OR = operating room; PI = pelvic incidence; $\mathrm{PSO}=$ pedicle subtraction osteotomy; TLIF = transforaminal lumbar interbody fusion. ACCOMPANYING EDITORIAL DOI: 10.3171/2017.6.FOCUS17390.

SUBMITTED April 1, 2017. ACCEPTED May 22, 2017.

INCLUDE WHEN CITING DOI: 10.3171/2017.5.FOCUS17195. 
successful in restoring spinopelvic harmony, this approach is associated with high surgical and postoperative morbidity. $., 9,13,26,31,66,72$

The minimally invasive lateral lumbar interbody fusion (LLIF) ${ }^{17}$ first popularized by Pimenta in $2001^{54}$ based on earlier case series ${ }^{16,36,42}$ has been used as an alternative to anterior lumbar interbody fusion and transforaminal lumbar interbody fusion (TLIF). ${ }^{17,27,68,81}$ A number of studies have demonstrated the use of standard LLIF in the correction of mild sagittal- and coronal-plane deformities. ${ }^{1,2,7,15,23,24,27,37,48,56,57,62}$ More advanced techniques involving the use of hyperlordotic cages with anterior longitudinal ligament (ALL) release and anterior column realignment (ACR) via a lateral technique allow for a significant gain in LL with the added benefit of coronal balance restoration and indirect neuroforaminal decompression at

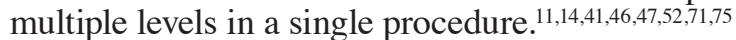

Here we compare our series of patients undergoing PSO or multiple-level LLIF with ACR for the correction of ASD and examine intraoperative estimated blood loss (EBL), operative time, length of stay (LOS), and change in spinopelvic parameters as well as perioperative and postoperative complications.

\section{Methods}

This study was approved by the institutional review board of Virginia Mason Medical Center. All patients were treated at Virginia Mason Hospital. We performed a retrospective chart review of all ASD correction cases involving a lumbar PSO and/or LLIF-ACR between 2010 and 2015 that qualified for inclusion based on the following criteria. Inclusion criteria were 1) a surgical procedure including either the use of a PSO or the use of hyperlordotic $\left(20^{\circ}\right.$ or $30^{\circ}$ ) laterally placed interbody cages (NuVasive); and 2) standing lateral preoperative and postoperative films that included the lumbar spine and femoral heads. Patients who had a PSO in the setting of a preexisting lumbar fusion that spanned more than 4 levels were excluded, as were patients who had a PSO that also included the placement of hyperlordotic lateral implants (any graft with angulation $>15^{\circ}$ ). Patients were excluded if they had received any antifibrinolytics preoperatively or intraoperatively, which became a part of our systematic operative protocol in mid2015 , in order to prevent confounding of the data between patients who had or had not received antifibrinolytics. Demographic information, spinopelvic parameters (LL and PI), level of graft placement, angulation of each LLIF graft, intraoperative EBL, operative time, and LOS were gathered from this chart analysis. Full spinopelvic parameters (e.g., sagittal vertical axis [SVA] and T1 spinopelvic angle) were not gathered for these patients as some earlier patients who underwent surgery before 2012 did not have reliable full-length scoliosis radiographs and our focus in this study was on correction of LL primarily. For staged procedures, intraoperative EBL and operating room (OR) time were combined to yield the sum that covered the entire operative intervention. All images were loaded into Surgimap software (Nemaris, Inc.) for measurement. A total of 27 patients who met the criteria for inclusion in the study were identified. The patients were separated into
TABLE 1. Summary of demographic and preoperative clinical characteristics

\begin{tabular}{|c|c|c|c|}
\hline \multirow[b]{2}{*}{ Characteristic } & \multicolumn{2}{|c|}{ Group } & \multirow{2}{*}{$\begin{array}{c}p \\
\text { Value }\end{array}$} \\
\hline & PSO $(n=14)$ & LLIF-ACR $(n=13)$ & \\
\hline Male, $\mathrm{n}(\%)$ & $7(50.0)$ & $7(53.85)$ & $>0.99$ \\
\hline Age in yrs & & & 0.207 \\
\hline Median & 65.9 & 62.3 & \\
\hline IQR & $62.8-68.8$ & $58.9-68.1$ & \\
\hline $\mathrm{BMl}$ in $\mathrm{kg} / \mathrm{m}^{2}$ & & & 0.207 \\
\hline Median & 26.6 & 30.9 & \\
\hline IQR & $21.8-33.2$ & $27.1-31.9$ & \\
\hline Preop LL $\left({ }^{\circ}\right)$ & & & 0.63 \\
\hline Mean & 20.2 & 23.0 & \\
\hline Range & $1-53$ & -16 to 40 & \\
\hline Preop PI $\left({ }^{\circ}\right)$ & & & 0.41 \\
\hline Mean & 52.6 & 26.1 & \\
\hline Range & $36-81$ & $45-74$ & \\
\hline Preop PI-LL $\left({ }^{\circ}\right)$ & & & 0.90 \\
\hline Mean & 32.4 & 33.1 & \\
\hline Range & $12-55$ & $16-77$ & \\
\hline
\end{tabular}

$\mathrm{BMI}=$ body mass index; $I \mathrm{QR}=$ interquartile range.

2 groups (the PSO group and the LLIF-ACR group) for data analysis depending on the primary means of lumbar lordosis correction. Summary statistics were generated for all demographic and operative parameters and compared between the 2 groups using 2 -tailed t-tests (see Tables 1 and 2); $<<0.05$ was considered statistically significant.

\section{Results}

The PSO group consisted of 14 patients (mean age 65.4 years, range 54-78 years, SD 6.3 years) who had a PSO and posterior fusion. Table 3 summarizes the operative characteristics of this group, including fixation and PSO levels. The total procedure was a single-stage operation in $3(21 \%)$ of 14 patients while the majority had a staged procedure with pedicle screw instrumentation placement on one day followed by the PSO and correction 2-3 days later (11 patients, 79\%). L5-S1 interbody fusion via TLIF was completed as part of the posterior procedure in 13/14 patients (93\%) with 1 patient having an L5-S1 anterior lumbar interbody fusion (ALIF) (7\%). Interbody fusion above and below the PSO location was completed via either posterior TLIF and/or via a lateral approach in 6/14 patients. In the patients who had a lateral interbody fusion at the levels above and below the PSO, the graft angulation was either $0^{\circ}$ or $10^{\circ}$. Bone morphogenetic protein (BMP) was used in 12 of these 14 patients. Our general practice during this time period was to use BMP in any TLIF cages, typically one-half of a sponge, and to lay the remaining 3.5 sponges of a medium kit (Medtronic) along the posterolateral arthrodesed segments of the lumbar spine. BMP was not used in patients with a prior history of any cancer or a strong family history of cancer. Figure 1 provides an example of a patient with PSO correction (PSO Case 1).

The LLIF-ACR group consisted of 13 patients (mean 
TABLE 2. Operative parameters

\begin{tabular}{|c|c|c|c|}
\hline \multirow[b]{2}{*}{ Parameter } & \multicolumn{2}{|c|}{ Group } & \multirow[b]{2}{*}{$\begin{array}{c}p \\
\text { Value }\end{array}$} \\
\hline & $\begin{array}{c}\text { PSO } \\
(n=14)\end{array}$ & $\begin{array}{c}\text { LLIF-ACR } \\
(n=13)\end{array}$ & \\
\hline LOS in days (from 1st stage) & & & 0.750 \\
\hline Mean & 8.9 & 9.5 & \\
\hline Range & $7-12$ & $7-10$ & \\
\hline $\begin{array}{l}\text { LOS in days (from PSO or XLH } \\
\text { portion) }\end{array}$ & & & 0.099 \\
\hline Mean & 7 & 7 & \\
\hline Range & $5-7$ & $7-10$ & \\
\hline EBL in ml (for PSO or XLH stage) & & & 0.003 \\
\hline Mean & 2500 & 800 & \\
\hline Range & $1100-2800$ & $250-1200$ & \\
\hline EBL in $\mathrm{ml}$ (for all stages) & & & 0.007 \\
\hline Mean & 2910 & 1466 & \\
\hline Range & $1800-3600$ & $1000-1800$ & \\
\hline Postop complications, n (\%) & $8(57.1)$ & $2(15.4)$ & 0.046 \\
\hline Reoperations w/in 30 days, $n(\%)$ & $2(14.3)$ & $0(0.0)$ & 0.481 \\
\hline Reoperation beyond 30 days & & & 0.596 \\
\hline No. of operations & 4 & 2 & \\
\hline No. of pts involved (\%) & $3(21.4)$ & $1(7.7)$ & \\
\hline \multicolumn{4}{|l|}{ Reoperation for pseudarthrosis } \\
\hline No. of operations & 3 & 0 & \\
\hline No. of pts involved (\%) & $2(14.3)$ & $0(0.0)$ & 0.522 \\
\hline \multicolumn{4}{|l|}{ Length of follow-up in mos } \\
\hline Median & 25.5 & 13.2 & 0.091 \\
\hline IQR & $5.0-73.6$ & $4.3-25.3$ & \\
\hline No. of cases w/ BMP utilized (\%) & $12(86)$ & $11(85)$ & 0.939 \\
\hline
\end{tabular}

Pts = patients; $\mathrm{XLH}=$ CoRoent $\mathrm{XL}-\mathrm{H}$, NuVasive . age 62.5 years, range 52-73 years, SD 6.3 years) who had a lateral approach initially with hyperlordotic interbody graft placement. Table 4 summarizes the demographic and operative characteristics of this group, including fixation and interbody levels. This lateral plus posterior procedure was completed in a single day (in 5 patients, 38\%) or as a staged procedure with lateral graft placement on 1 day followed by the placement of posterior instrumentation 2-3 days later (8 patients, 62\%). Since the lateral approach is unable to supply interbody fusion at L5-S1, all of these patients had an L5-S1 TLIF graft placed as part of the posterior procedure. Most patients had multiple hyperlordotic grafts placed, with total angulation of grafts implanted ranging from $30^{\circ}$ to $90^{\circ}$. BMP was used in 11 of 13 patients, in the fashion described above with similar exclusions. Figure 2 provides an example of an LLIF-ACR case with interbody placement at L2-3, L3-4, and L4-5 (LLIF-ACR Case 8).

The mean value for total intraoperative EBL was significantly lower in the LLIF-ACR group, approximately 50\% mean EBL in the PSO group (1466 vs $2910 \mathrm{ml}$, p < 0.01). The total correction in LL was equivalent between the 2 groups $\left(35^{\circ}\right.$ in the PSO group, $31^{\circ}$ in the LLIF-ACR group, $\mathrm{p}>0.05)$. The mean preoperative PI-LL mismatch was equivalent at $33^{\circ}$ in each group $\left(\mathrm{p}>0.05\right.$; range $12^{\circ}-55^{\circ}$ in the PSO group and $16^{\circ}-77^{\circ}$ in the LLIF-ACR group). The postoperative PI-LL mismatch was likewise equivalent in the 2 groups $(\mathrm{p}>0.05)$ with an average of $-0.6^{\circ}$ in the PSO group (range $-12^{\circ}$ to $24^{\circ}, \mathrm{SD} 10.7^{\circ}$ ) and $0.8^{\circ}$ in the LLIF-ACR group (range $-11^{\circ}$ to $22^{\circ}$, SD $10.22^{\circ}$ ). The total operative time and LOS did not differ significantly between the 2 groups (mean 9 hours 43 minutes vs 9 hours 22 minutes, $\mathrm{p}>0.05$; and 8.85 days vs 9.5 days, $\mathrm{p}>0.05$ ). The total number of levels fused did not differ significantly between groups (a mean of 9.3 levels in the PSO group

TABLE 3. Clinical summary: PSO group

\begin{tabular}{|c|c|c|c|c|c|c|c|c|c|c|c|c|}
\hline \multirow{2}{*}{$\begin{array}{l}\text { Case } \\
\text { No. }\end{array}$} & \multirow{2}{*}{$\begin{array}{c}\text { Age (yrs) } \\
\text { Sex }\end{array}$} & \multirow{2}{*}{$\begin{array}{l}\text { Fixation } \\
\text { Levels }\end{array}$} & \multicolumn{4}{|c|}{ Implanted Grafts $\left(^{\circ}\right)$} & \multirow{2}{*}{$\begin{array}{l}\text { PSO } \\
\text { Level }\end{array}$} & \multicolumn{2}{|c|}{ Preop } & \multicolumn{2}{|c|}{ Postop } & \multirow{2}{*}{$\begin{array}{l}\text { LL } \\
\text { Corr }\end{array}$} \\
\hline & & & L1-2 & L2-3 & L3-4 & L4-5 & & $\mathrm{LL}$ & PI-LL & $\mathrm{LL}$ & PI-LL & \\
\hline 1 & $65, M$ & T10-pelvis & & & & & L-3 & 21 & 23 & 56 & -12 & 35 \\
\hline 2 & $68, M$ & T10-pelvis & 10 & 10 & 10 & 10 & L-2 & 19 & 24 & 58 & -12 & 39 \\
\hline 3 & $71, \mathrm{~F}$ & T4-pelvis & & 0 & 0 & & L-3 & 30 & 38 & 67 & 5 & 37 \\
\hline 4 & $78, \mathrm{~F}$ & T10-pelvis & & & 0 & & L-3 & 1 & 35 & 40 & -6 & 39 \\
\hline 5 & $55, \mathrm{~F}$ & T10-pelvis & & & & 10 & $L-5$ & 17 & 42 & 61 & 6 & 44 \\
\hline 6 & $67, \mathrm{~F}$ & T9-pelvis & & 10 & 10 & 10 & L-3 & 53 & 28 & 77 & 4 & 24 \\
\hline 7 & $69, \mathrm{~F}$ & T10-pelvis & & 10 & 10 & 10 & L-3 & 16 & 33 & 62 & -11 & 46 \\
\hline 8 & $70, \mathrm{~F}$ & T10-pelvis & & 0 & 0 & 0 & L-3 & 28 & 28 & 48 & 8 & 20 \\
\hline 9 & $63, M$ & T10-pelvis & & & & & L-3 & 3 & 48 & 42 & 9 & 39 \\
\hline 10 & $67, \mathrm{M}$ & L2-pelvis & & & & & $L-4$ & 32 & 19 & 54 & -2 & 22 \\
\hline 11 & $64, \mathrm{~F}$ & T10-pelvis & & & & & L-3 & 28 & 12 & 51 & -11 & 23 \\
\hline 12 & $61, M$ & T10-pelvis & & & & & L-3 & 1 & 55 & 32 & 24 & 31 \\
\hline 13 & $63, \mathrm{M}$ & T10-pelvis & & & & & L-3 & 2 & 46 & 47 & 1 & 45 \\
\hline 14 & $54, \mathrm{M}$ & T10-pelvis & & 10 & 10 & & L-3 & 32 & 22 & 60 & -11 & 28 \\
\hline
\end{tabular}

Corr = correction.

Clinical summary of 14 cases involving patients with ASD treated using a PSO at L-2, L-3, L-4, or L-5 along with, in some cases, lateral interbody fusion with $0^{\circ}$ or $10^{\circ}$ grafts; 13 of 14 patients underwent an L5-S1 TLIF in addition to the above-mentioned grafts, with 1 patient having L5-S1 ALIF. 


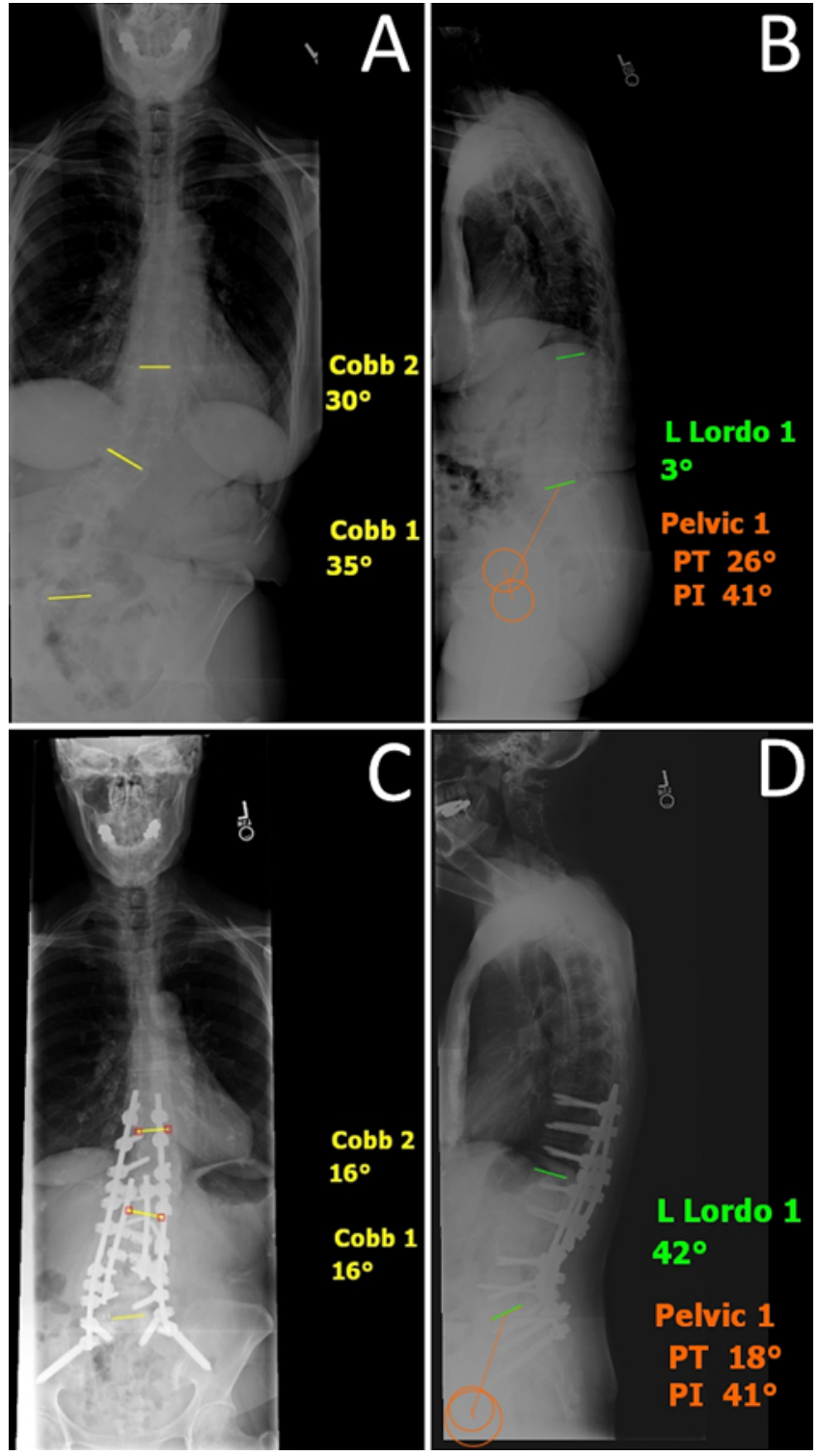

FIG. 1. Case 1 from the PSO Group. Preoperative (A and B) and postoperative (C and $\mathbf{D})$ standing scoliosis radiographs of a patient who underwent L-3 PSO with T10-pelvis posterior fixation with L4-5, L5-S1 TLIF for flat-back deformity. The preoperative coronal radiograph (A) demonstrates a $30^{\circ}$ thoracolumbar curve with a $35^{\circ}$ lumbosacral curve, while the preoperative sagittal radiograph $(B)$ demonstrates an $L L$ of $3^{\circ}$ and a $\mathrm{PI}$ of $41^{\circ}$, for a mismatch of $38^{\circ}$. The postoperative coronal radiograph (C) demonstrates that both curves have been reduced to $16^{\circ}$, and the postoperative sagittal radiograph $(\mathrm{D})$ demonstrates appropriate $\mathrm{PI}-\mathrm{LL}$ matching. Cobb = Cobb angle; $\mathrm{L}$ Lordo = lumbar lordosis; $\mathrm{PT}=$ pelvic tilt.

vs 11 levels in the LLIF-ACR group, $\mathrm{p}=0.22$ ). Within the LLIF-ACR group, the most common total cage angle of inserted lateral grafts was $50^{\circ}$ (range $30^{\circ}-90^{\circ}$, average $61^{\circ}$ ), and the average number of lateral grafts inserted was 3 (range 1-4). The lordosis correction reported as a percentage of total implanted cage angle ranged from $12 \%$ to $164 \%$, with an average of $54 \%$, suggesting that in most patients the amount of lordosis gained was approximately half of the inserted cage angle.

Complications were collected as perioperative (within
30 days of surgery) and postoperative beyond 30 days after surgery (Tables 5 and 6). Eight patients in the PSO group had a perioperative complication, with 2 of these complications likely representing direct surgical issues, including a wound infection requiring washout in one patient and postoperative quadriceps weakness in another patient, requiring a return to the OR for relaxation of the correction at the PSO site. This patient subsequently saw an improvement back to normal function over the next 4 months. Two patients in the LLIF-ACR group had perioperative complications, although there were no direct approach-related injuries, such as iliac injury, lumbar plexus injury, or bowel perforation. Three of 14 patients in the PSO group required reoperation beyond 30 days, with 2 patients having a fracture at the PSO site requiring revision and 1 patient undergoing removal of a painful iliac bolt. One of the patients who had a rod fracture patients subsequently had a second rod fracture requiring revision. In the LLIF-ACR group, 1 patient required reoperation due to proximal junctional failure shortly after the index procedure and subsequently required an additional procedure for revision of a nonhealing wound. There were no rod fractures or pseudarthroses in the LLIF-ACR group, although the overall duration of follow-up for this group was lower, which constitutes a potential source of bias in our results.

\section{Discussion}

The PSO remains a mainstay of fixed sagittal balance correction for deformity surgeons, especially when approaching patients with a flat-back ${ }^{79}$ or kyphotic deformity. ${ }^{9} 12$ There are numerous disadvantages associated with the PSO, however, including increases in operative time and blood loss, as well as an increase in risk of neurological dysfunction, morbidity, and mortality.,20 Although institutional protocols involving staged surgery, ${ }^{59}$ a dual deformity surgeon approach, ${ }^{3,67}$ hybrid techniques encompassing open and percutaneous pedicle screw placement, ${ }^{4,25,40,49-51}$ the use of preoperative medications such as tranexamic acid (TXA) to reduce blood loss, ${ }^{32}$ and intraoperative neuromonitoring have reduced the morbidity of the PSO, perioperative complication rates remain high. Less invasive PSO techniques have been developed, but they have also not substantially reduced these risks. ${ }^{22}$

Moreover, the PSO technique does not restore LL in a harmonious manner, instead relying on achieving the majority of the deformity correction across a single segment of the spine..$^{10,13}$ The significant focal curvature may increase the risk of neurological injury due to dural bucking and the risk of hardware failure due to rod fracture and may be associated with higher rates of proximal junctional kyphosis due to nonharmonious realignment. ${ }^{10,13,21,30,38,44,45,55,61,80}$ Techniques utilizing bridging rods or novel rod constructs have decreased but not eliminated this risk. . $^{10,38,44,45,55,61}$

The anterior column resection (ACR) technique was first described in 2011 as a means of increasing the lordosis that could be obtained by lateral interbody grafts, more similar in correction to an anteriorly placed graft than the conventional lateral grafts that had been used up until that point in time..$^{14,58,75}$ Parallel and mildly lordotic 
TABLE 4. Clinical summary: LLIF-ACR group

\begin{tabular}{|c|c|c|c|c|c|c|c|c|c|c|c|c|}
\hline \multirow{2}{*}{$\begin{array}{l}\text { Case } \\
\text { No. }\end{array}$} & \multirow{2}{*}{$\begin{array}{c}\text { Age (yrs), } \\
\text { Sex }\end{array}$} & \multirow{2}{*}{$\begin{array}{c}\text { Fixation } \\
\text { Levels }\end{array}$} & \multicolumn{4}{|c|}{ Implanted Grafts $\left(^{\circ}\right)$} & \multirow[b]{2}{*}{ Total } & \multicolumn{2}{|c|}{ Preop } & \multicolumn{2}{|c|}{ Postop } & \multirow{2}{*}{$\begin{array}{l}\text { LL } \\
\text { Corr }\end{array}$} \\
\hline & & & L1-2 & L2-3 & L3-4 & L4-5 & & LL & PI-LL & LL & PI-LL & \\
\hline 1 & $63, F$ & T10-pelvis & 30 & 20 & 30 & 10 & 90 & 24 & 37 & 55 & 4 & 31 \\
\hline 2 & $73, \mathrm{M}$ & L2-5 & & 20 & 30 & 10 & 60 & 32 & 16 & 41 & 5 & 9 \\
\hline 3 & $52, \mathrm{M}$ & T10-pelvis & & 20 & 30 & & 50 & 33 & 24 & 61 & -4 & 28 \\
\hline 4 & $62, \mathrm{M}$ & T9-pelvis & & 30 & 20 & 30 & 80 & 14 & 31 & 48 & -9 & 34 \\
\hline 5 & $68, F$ & T3-pelvis & & 20 & 30 & 30 & 80 & 30 & 29 & 61 & 6 & 21 \\
\hline 6 & $54, \mathrm{~F}$ & T4-pelvis & 30 & & & & 30 & 20 & 26 & 51 & -8 & 31 \\
\hline 7 & $58, M$ & L1-5 & & 20 & 30 & & 50 & -16 & 77 & 66 & -7 & 82 \\
\hline 8 & $70, M$ & T4-pelvis & & 20 & 20 & 30 & 70 & 23 & 29 & 56 & -7 & 33 \\
\hline 9 & $59, \mathrm{~F}$ & T4-pelvis & 20 & & & 30 & 60 & 11 & 34 & 55 & -11 & 44 \\
\hline 10 & $60, \mathrm{~F}$ & T4-pelvis & 15 & 20 & 30 & & 65 & 22 & 52 & 57 & 14 & 35 \\
\hline 11 & $60, \mathrm{~F}$ & T2-pelvis & & 15 & 15 & 30 & 60 & 32 & 25 & 47 & 10 & 15 \\
\hline 12 & $71, \mathrm{M}$ & T10-pelvis & & 15 & 20 & 20 & 55 & 26 & 20 & 46 & -5 & 20 \\
\hline 13 & $63, \mathrm{M}$ & T10-pelvis & & 20 & 20 & 15 & 55 & 38 & 30 & 45 & 22 & 7 \\
\hline
\end{tabular}

Clinical summary of 13 cases involving patients with ASD treated using hyperlordotic lateral interbody grafts. All $20^{\circ}$ and $30^{\circ}$ grafts were performed with an ACR technique with ALL release; $10^{\circ}$ and $15^{\circ}$ grafts were placed without ALL release. All patients underwent an L5-S1 TLIF in addition to the above-mentioned grafts.

$\left(5^{\circ}-10^{\circ}\right)$ lateral grafts have been used to treat scoliotic curvatures with reasonable results, but these corrections are typically much more impressive in the coronal plane than the sagittal plane, suggesting that lateral techniques may apply primarily to treatment of patients with minimal or no sagittal imbalance. ${ }^{27-29}$ Typical lordosis restoration with these standard lateral grafts without sectioning of the ALL ranges from $4^{\circ}-9^{\circ}$ at each level, allowing for modest correction of a sagittal plane deformity. $1,2,23,35,53,57,62,69,74,77,78$

With the advent of lateral grafts with $20^{\circ}-30^{\circ}$ of angulation and sectioning of the ALL, ${ }^{29}$ however, much more profound focal and regional curvature can be obtained, typically averaging about $50 \%$ of the inserted graft angle $\left(10^{\circ}-17^{\circ}\right) .^{11,14,41,71,73,75}$ Case series have demonstrated that the procedure can be performed safely, with blood loss ranging from 40 to $150 \mathrm{ml}$ and with a complication rate similar to that observed with standard lateral transpsoas approaches. ${ }^{11,29,58}$ This technique does have some limitations, however, as it generally cannot be used in cases of previous posterior fusion without some form of release, and almost never in cases of a previous interbody fusion unless a pseudarthrosis is present. Its primary use, therefore, is in patients with no prior fusion or a limited-segment lumbar fusion who are presenting with spinopelvic mismatch.

Our current study primarily attempts to compare the intraoperative and pre- and postoperative radiographic parameters of patients undergoing correction of a spinopelvic mismatch with either a PSO or with the use of lateral ACR with hyperlordotic cage placement (LLIF-ACR). The average spinopelvic mismatch between LL and PI was greater than $30^{\circ}$ in each group preoperatively. As noted in Methods, we excluded patients from the PSO group who had an extensive preexisting fusion; these patients would not be candidates for LLIF-ACR and would generally require a PSO for correction. This strict inclusion criterion limits the overall number of patients in the study, but hopefully provides a greater degree of clinical equipoise between the 2 groups, as we are comparing parameters between patients who theoretically could have had either procedure as a means of sagittal plane correction.

We find that PSO and multilevel LLIF-ACR generate equivalent lordosis and restoration of spinopelvic matching. Both groups had $30^{\circ}-35^{\circ}$ of lumbar lordosis correction. However, patients undergoing LLIF-ACR had significantly less operative blood loss without any significant increase in perioperative/postoperative complications or need for reoperation. This study represents the first direct comparison between PSO and LLIF-ACR, as previous case series have typically described the results of LLIF-ACR and compared results to literature reports of outcomes after PSO, and it demonstrates that LLIF-ACR is able to provide the correction needed even for patients with profound spinopelvic mismatch. We did not find any substantial difference in operative time between the 2 groups, likely because the LLIF-ACR portion of the procedure does necessitate a separate positioning, opening, and closing, as compared with a PSO, in which instrumentation placement and the osteotomy can be performed through a single incision. In addition, we did not see any difference in total LOS. With the increase in the use of preoperative antifibrinolytics, the high EBL reported in our PSO group and by others describing PSOs may be reduced, making this difference between the 2 groups less clinically significant.

One notable limitation of this study is the lack of longterm follow-up for all patients beyond 1 year. Another limitation is the lack of information regarding functional outcomes..$^{70}$ While we do currently gather these data clinically, some patients within the PSO group did not have these data available for review, so they are not reported here. Likewise, there is a lack of data regarding minor adverse outcomes, although we can report that no patients in either group experienced a major complication of bowel injury, ${ }^{8}$ hardware failure within 30 days, or death. There have been 2 recent studies suggesting that neurological 

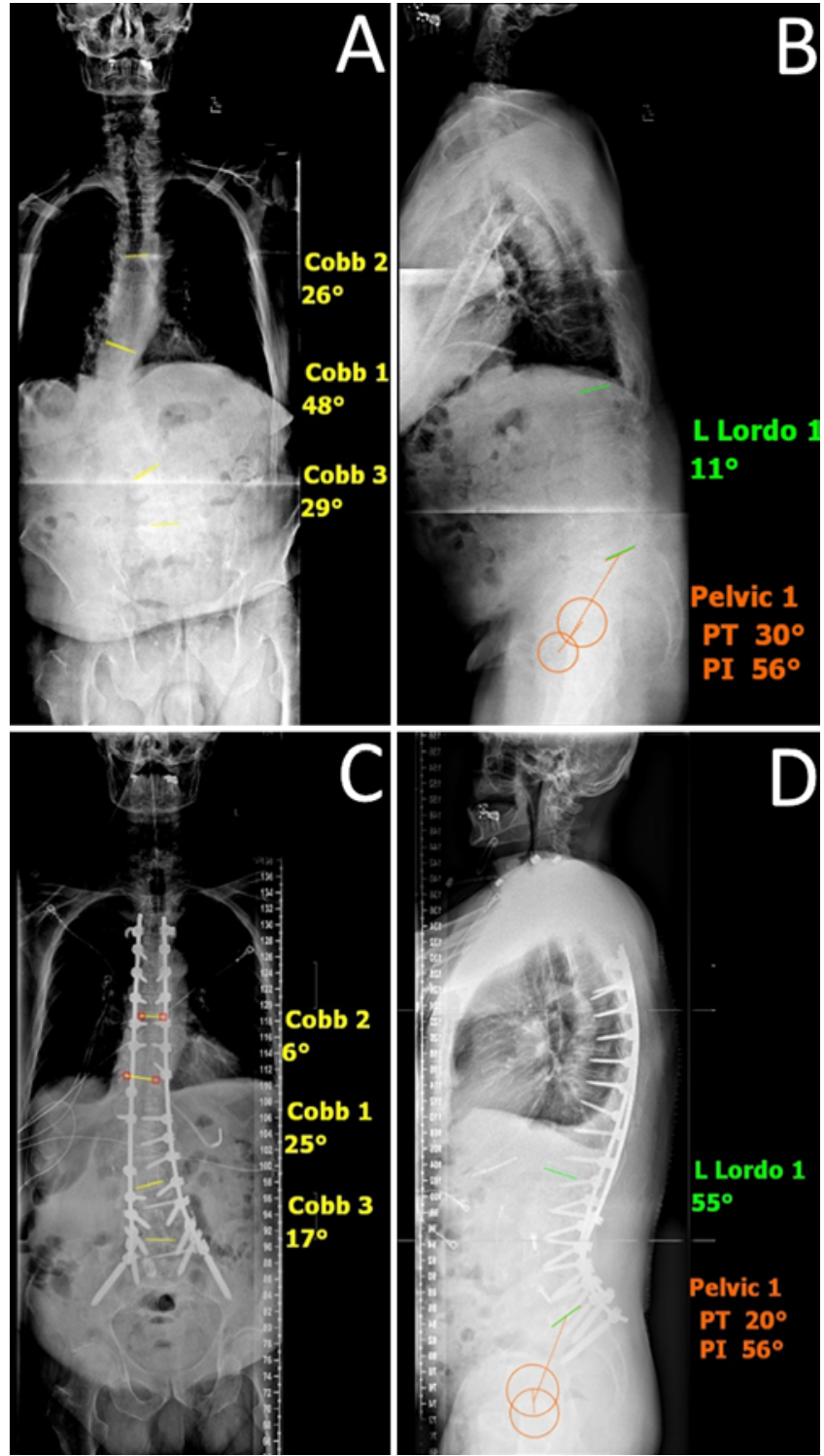

FIG. 2. Case 8 from the LLIF-ACR Group. Preoperative (A and B) and postoperative ( $C$ and $\mathbf{D}$ ) standing scoliosis radiographs of a patient who underwent L2-3, L3-4, and L4-5 LLIF-ACR with T10-pelvis posterior fixation for flat-back deformity. The preoperative coronal radiograph $(A)$ demonstrates a $48^{\circ}$ thoracolumbar curve with a $29^{\circ}$ fractional lumbosacral curve, while the preoperative sagittal radiograph (B) demonstrates an $\mathrm{LL}$ of $11^{\circ}$ and $\mathrm{PPI}$ of $56^{\circ}$, for a mismatch of $45^{\circ}$. The postoperative coronal radiograph $(\mathrm{C})$ demonstrates that the curves have been reduced to $25^{\circ}$ and $17^{\circ}$ respectively, and the postoperative sagittal radiograph (D) demonstrates appropriate PI-LL matching.

complications with LLIF-ACR are less than with PSO, $, 2,60$ and this is supported by our data from the present study, although further studies will be needed to substantiate this assertion.

Another clinical limitation is the current general challenge of creating a detailed preoperative plan for ACR correction. It is important to note that even with the PSO, exact correction may be hard to determine preoperatively, and we have recently demonstrated that correction changes from intraoperative films to postoperative films by $13^{\circ} .43$ Although surgical planning software ${ }^{6,39}$ can make preop-
TABLE 5. Perioperative complications

\begin{tabular}{|c|c|c|c|}
\hline $\begin{array}{l}\text { Group \& } \\
\text { Case No. }\end{array}$ & Complication & $\begin{array}{l}\text { Reoperation } \\
\text { Required? }\end{array}$ & $\begin{array}{l}\text { Reoperation } \\
\text { (procedure) }\end{array}$ \\
\hline \multicolumn{4}{|l|}{ PSO Group } \\
\hline Case 3 & Wound infection & Yes & Washout \\
\hline Case 4 & $\begin{array}{c}\text { Trochanteric } \\
\text { bursitis }\end{array}$ & No & \\
\hline Case 7 & UTI & No & \\
\hline Case 8 & Delirium, ileus & No & \\
\hline Case 9 & $\begin{array}{l}\text { Quadriceps } \\
\text { weakness }\end{array}$ & Yes & $\begin{array}{l}\text { Slight relaxation } \\
\text { of correction } \\
\text { at PSO }\end{array}$ \\
\hline Case 10 & Fever & No & \\
\hline Case 11 & Neuritis & No & \\
\hline Case 14 & Delirium, ileus & No & \\
\hline \multicolumn{4}{|c|}{ LLIF-ACR Group } \\
\hline Case 10 & Costochondritis & No & \\
\hline Case 12 & Fever, DVT & No & \\
\hline
\end{tabular}

$\mathrm{UTI}=$ urinary tract infection.

erative planning more exact, it cannot fully account for the intraoperative state. Our experience with LLIF-ACR presented here resembles that described by other groups, in that the degree of lordosis created at a particular level can vary substantially independent of the graft angulation inserted. We reported on the increase in focal lordosis as a percentage of the graft angulation inserted, such that a patient who had an increase of $15^{\circ}$ in segmental lordosis after insertion of a $30^{\circ}$ lordotic graft would have a $50 \%$ correction. Our average lordosis gain was $54 \%$ of total cage angle, but the results were variable. In patients with a focal kyphosis, we generally observed a correction greater than $50 \%$, in one instance up to $164 \%$, while in other cases, lordosis gain was more modest, typically reduced by subsidence during cage insertion. ${ }^{47}$ In cases of intraoperative graft subsidence, we typically adjusted the cage angle that was planned for adjacent levels or considered adding another level of interbody graft. This intraoperative modification of the surgical plan has allowed us to achieve the desired correction in almost all cases. Continued development of preoperative planning software to account for these intraoperative factors will improve the reliability of this technique for deformity correction.

We do not envision that the LLIF-ACR will completely replace the PSO, but rather that it can serve as a useful alternative with less risk for patients with unfused disc levels. Current ACR techniques may also allow for the future development of minimally invasive scoliosis correction techniques even in patients with sagittal plane imbalance who remain some of the more difficult patients to treat via minimally invasive approaches.

\section{Conclusions}

This is the first single-institution direct comparison of the LLIF-ACR technique with the PSO in ASD correction. We have demonstrated that the LLIF-ACR provides 
TABLE 6. Reoperation at more than 30 days after the index procedure

\begin{tabular}{|c|c|c|c|}
\hline Group \& Case No. & Reason for Reoperation & Reoperation & Time After Index Op (mos) \\
\hline \multicolumn{4}{|l|}{ PSO Group } \\
\hline Case 11 & Symptomatic left iliac bolt & Iliac bolt removal & 10.8 \\
\hline Case 12 & Rod fracture at $L 4-5$ & Revision fusion at $L 4-5$ & 4.8 \\
\hline Case 13 & Rod fracture at PSO site & Revision fusion at PSO & 19.3 \\
\hline Case 13 & Unilateral rod fracture L1-2 & Lateral interbody graft T12-L1 \& L1-2 & 63.3 \\
\hline \multicolumn{4}{|l|}{ LLIF-ACR Group } \\
\hline Case 2 & Proximal junctional failure & Extension of fusion up to $\mathrm{T}-10 \mathrm{w} /$ pelvic fixation & 1.5 \\
\hline Case 2 & Nonhealing wound & Revision of wound & 3 \\
\hline
\end{tabular}

equivalent deformity correction compared with the PSO in patients with significant spinopelvic mismatch and a previously unfused spine, with significantly reduced blood loss. This technique provides a powerful means to avoid the PSO in selected patients who require spinal deformity correction and may make spinal deformity surgery accessible to a broader range of patients. Future studies of LLIF-ACR will be necessary to elucidate the long-term outcomes of this technique compared with the PSO.

\section{References}

1. Acosta FL, Liu J, Slimack N, Moller D, Fessler R, Koski T: Changes in coronal and sagittal plane alignment following minimally invasive direct lateral interbody fusion for the treatment of degenerative lumbar disease in adults: a radiographic study. J Neurosurg Spine 15:92-96, 2011

2. Alimi M, Hofstetter CP, Cong GT, Tsiouris AJ, James AR, Paulo D, et al: Radiological and clinical outcomes following extreme lateral interbody fusion. J Neurosurg Spine 20:623-635, 2014

3. Ames CP, Barry JJ, Keshavarzi S, Dede O, Weber MH, Deviren V: Perioperative outcomes and complications of pedicle subtraction osteotomy in cases with single versus two attending surgeons. Spine Deform 1:51-58, 2013

4. Ames CP, Smith JS, Scheer JK, Bess S, Bederman SS, Deviren $\mathrm{V}$, et al: Impact of spinopelvic alignment on decision making in deformity surgery in adults: a review. J Neurosurg Spine 16:547-564, 2012

5. Anand N, Baron EM: Minimally invasive approaches for the correction of adult spinal deformity. Eur Spine J 22 (Suppl 2):S232-S241, 2013

6. Aubin CE, Labelle H, Chevrefils C, Desroches G, Clin J, Eng AB: Preoperative planning simulator for spinal deformity surgeries. Spine (Phila Pa 1976) 33:2143-2152, 2008

7. Baghdadi YM, Larson AN, Dekutoski MB, Cui Q, Sebastian AS, Armitage BM, et al: Sagittal balance and spinopelvic parameters after lateral lumbar interbody fusion for degenerative scoliosis: a case-control study. Spine (Phila Pa 1976) 39:E166-E173, 2014

8. Balsano M, Carlucci S, Ose M, Boriani L: A case report of a rare complication of bowel perforation in extreme lateral interbody fusion. Eur Spine J 24 (Suppl 3):405-408, 2015

9. Barrey C, Perrin G, Michel F, Vital JM, Obeid I: Pedicle subtraction osteotomy in the lumbar spine: indications, technical aspects, results and complications. Eur J Orthop Surg Traumatol 24 (Suppl 1):S21-S30, 2014

10. Barton C, Noshchenko A, Patel V, Cain C, Kleck C, Burger E: Risk factors for rod fracture after posterior correction of adult spinal deformity with osteotomy: a retrospective caseseries. Scoliosis 10:30, 2015
11. Beckman JM, Marengo N, Murray G, Bach K, Uribe JS: Anterior longitudinal ligament release from the minimally invasive lateral retroperitoneal transpsoas approach: technical note. Oper Neurosurg (Hagerstown) 12:214-221, 2016

12. Berjano P, Aebi M: Pedicle subtraction osteotomies (PSO) in the lumbar spine for sagittal deformities. Eur Spine J 24 (Suppl 1):S49-S57, 2015

13. Berjano P, Bassani R, Casero G, Sinigaglia A, Cecchinato R, Lamartina $C$ : Failures and revisions in surgery for sagittal imbalance: analysis of factors influencing failure. Eur Spine J 22 (Suppl 6):S853-S858, 2013

14. Berjano P, Damilano M, Ismael M, Longo A, Bruno A, Lamartina C: Anterior column realignment (ACR) technique for correction of sagittal imbalance. Eur Spine J 24 (Suppl 3):451-453, 2015

15. Berjano $P$, Lamartina C: Far lateral approaches (XLIF) in adult scoliosis. Eur Spine J 22 (Suppl 2):S242-S253, 2013

16. Bertagnoli R, Vazquez RJ: The anterolateral transpsoatic approach (ALPA): a new technique for implanting prosthetic disc-nucleus devices. J Spinal Disord Tech 16:398-404, 2003

17. Billinghurst J, Akbarnia BA: Extreme lateral interbody fusion - XLIF. Curr Orthop Pract 20:238-251, 2009

18. Bradford DS, Tay BK, Hu SS: Adult scoliosis: surgical indications, operative management, complications, and outcomes. Spine (Phila Pa 1976) 24:2617-2629, 1999

19. Bridwell KH: Decision making regarding Smith-Petersen vs. pedicle subtraction osteotomy vs. vertebral column resection for spinal deformity. Spine (Phila Pa 1976) 31 (19 Suppl):S171-S178, 2006

20. Bridwell KH, Lewis SJ, Edwards C, Lenke LG, Iffrig TM, Berra A, et al: Complications and outcomes of pedicle subtraction osteotomies for fixed sagittal imbalance. Spine (Phila Pa 1976) 28:2093-2101, 2003

21. Bridwell KH, Lewis SJ, Rinella A, Lenke LG, Baldus C, Blanke K: Pedicle subtraction osteotomy for the treatment of fixed sagittal imbalance. Surgical technique. J Bone Joint Surg Am 86-A (Suppl 1):44-50, 2004

22. Chou D, Lau D: The mini-open pedicle subtraction osteotomy for flat-back syndrome and kyphosis correction: operative technique. Oper Neurosurg (Hagerstown) 12:309-316, 2016

23. Costanzo G, Zoccali C, Maykowski P, Walter CM, Skoch J, Baaj AA: The role of minimally invasive lateral lumbar interbody fusion in sagittal balance correction and spinal deformity. Eur Spine J 23 (Suppl 6):699-704, 2014

24. Dakwar E, Cardona RF, Smith DA, Uribe JS: Early outcomes and safety of the minimally invasive, lateral retroperitoneal transpsoas approach for adult degenerative scoliosis. Neurosurg Focus 28(3):E8, 2010

25. Dangelmajer S, Zadnik PL, Rodriguez ST, Gokaslan ZL, Sciubba DM: Minimally invasive spine surgery for adult degenerative lumbar scoliosis. Neurosurg Focus 36(5):E7, 2014 
26. Daubs MD, Brodke DS, Annis P, Lawrence BD: Perioperative complications of pedicle subtraction osteotomy. Global Spine J 6:630-635, 2016

27. Deukmedjian AR, Ahmadian A, Bach K, Zouzias A, Uribe JS: Minimally invasive lateral approach for adult degenerative scoliosis: lessons learned. Neurosurg Focus 35(2):E4, 2013

28. Deukmedjian AR, Dakwar E, Ahmadian A, Smith DA, Uribe JS: Early outcomes of minimally invasive anterior longitudinal ligament release for correction of sagittal imbalance in patients with adult spinal deformity. Sci World J 2012:789698, 2012

29. Deukmedjian AR, Le TV, Baaj AA, Dakwar E, Smith DA, Uribe JS: Anterior longitudinal ligament release using the minimally invasive lateral retroperitoneal transpsoas approach: a cadaveric feasibility study and report of 4 clinical cases. J Neurosurg Spine 17:530-539, 2012

30. Deviren V, Tang JA, Scheer JK, Buckley JM, Pekmezci M, McClellan RT, et al: Construct rigidity after fatigue loading in pedicle subtraction osteotomy with or without adjacent interbody structural cages. Global Spine J 2:213-220, 2012

31. Dickson DD, Lenke LG, Bridwell KH, Koester LA: Risk factors for and assessment of symptomatic pseudarthrosis after lumbar pedicle subtraction osteotomy in adult spinal deformity. Spine (Phila Pa 1976) 39:1190-1195, 2014

32. Elgafy H, Bransford RJ, McGuire RA, Dettori JR, Fischer D: Blood loss in major spine surgery: are there effective measures to decrease massive hemorrhage in major spine fusion surgery? Spine (Phila Pa 1976) 35 (9 Suppl):S47-S56, 2010

33. Glassman SD, Berven S, Bridwell K, Horton W, Dimar JR: Correlation of radiographic parameters and clinical symptoms in adult scoliosis. Spine (Phila Pa 1976) 30:682-688, 2005

34. Glassman SD, Bridwell K, Dimar JR, Horton W, Berven S, Schwab F: The impact of positive sagittal balance in adult spinal deformity. Spine (Phila Pa 1976) 30:2024-2029, 2005

35. Haque RM, Mundis GM Jr, Ahmed Y, El Ahmadieh TY, Wang MY, Mummaneni PV, et al: Comparison of radiographic results after minimally invasive, hybrid, and open surgery for adult spinal deformity: a multicenter study of 184 patients. Neurosurg Focus 36(5):E13, 2014

36. Husson JL, Le Huec JC, Polard JL, Trébuchet G, Lesprit E, Bossis JM: [Interbody arthrodesis of the lumbar vertebrae using retroperitoneal videoendoscopy. A preliminary study of 38 cases.] Chirurgie 123:491-499, 1998 (Fr)

37. Isaacs RE, Hyde J, Goodrich JA, Rodgers WB, Phillips FM: A prospective, nonrandomized, multicenter evaluation of extreme lateral interbody fusion for the treatment of adult degenerative scoliosis: perioperative outcomes and complications. Spine (Phila Pa 1976) 35 (26 Suppl):S322-S330, 2010

38. Jager ZS, İnceoğlu S, Palmer D, Akpolat YT, Cheng WK: Preventing instrumentation failure in three-column spinal osteotomy: biomechanical analysis of rod configuration. Spine Deform 4:3-9, 2016

39. Jamali AA: Digital templating and preoperative deformity analysis with standard imaging software. Clin Orthop Relat Res 467:2695-2704, 2009

40. Kanter AS, Tempel ZJ, Ozpinar A, Okonkwo DO: A review of minimally invasive procedures for the treatment of adult spinal deformity. Spine (Phila Pa 1976) 41 (Suppl 8):S59S65, 2016

41. Khajavi K, Shen AY: Two-year radiographic and clinical outcomes of a minimally invasive, lateral, transpsoas approach for anterior lumbar interbody fusion in the treatment of adult degenerative scoliosis. Eur Spine J 23:1215-1223, 2014

42. Le Huec JC, Liu M, Skalli W, Josse L: Lumbar lateral interbody cage with plate augmentation: in vitro biomechanical analysis. Eur Spine J 11:130-136, 2002
43. Leveque JC, Edwards A, Sethi RK: Preoperative, intraoperative, and postoperative standing lordosis after pedicle subtraction osteotomy: an analysis of radiographic parameters and surgical strategy. Spine Deform 4:245-250, 2016

44. Lindsey C, Deviren V, Xu Z, Yeh RF, Puttlitz CM: The effects of rod contouring on spinal construct fatigue strength. Spine (Phila Pa 1976) 31:1680-1687, 2006

45. Luca A, Lovi A, Galbusera F, Brayda-Bruno M: Revision surgery after PSO failure with rod breakage: a comparison of different techniques. Eur Spine J 23 (Suppl 6):610-615, 2014

46. Manwaring JC, Bach K, Ahmadian AA, Deukmedjian AR, Smith DA, Uribe JS: Management of sagittal balance in adult spinal deformity with minimally invasive anterolateral lumbar interbody fusion: a preliminary radiographic study. J Neurosurg Spine 20:515-522, 2014

47. Marchi L, Oliveira L, Amaral R, Castro C, Coutinho T, Coutinho E, et al: Anterior elongation as a minimally invasive alternative for sagittal imbalance - a case series. HSS J 8:122-127, 2012

48. McAfee PC, Shucosky E, Chotikul L, Salari B, Chen L, Jerrems D: Multilevel extreme lateral interbody fusion (XLIF) and osteotomies for 3-dimensional severe deformity: 25 consecutive cases. Int J Spine Surg 7:e8-e19, 2013

49. Mummaneni PV, Shaffrey CI, Lenke LG, Park P, Wang MY, La Marca F, et al: The minimally invasive spinal deformity surgery algorithm: a reproducible rational framework for decision making in minimally invasive spinal deformity surgery. Neurosurg Focus 36(5):E6, 2014

50. Mummaneni PV, Tu TH, Ziewacz JE, Akinbo OC, Deviren $\mathrm{V}$, Mundis GM: The role of minimally invasive techniques in the treatment of adult spinal deformity. Neurosurg Clin $\mathbf{N}$ Am 24:231-248, 2013

51. Mundis GM, Akbarnia BA, Phillips FM: Adult deformity correction through minimally invasive lateral approach techniques. Spine (Phila Pa 1976) 35 (26 Suppl):S312-S321, 2010

52. Murray G, Beckman J, Bach K, Smith DA, Dakwar E, Uribe JS: Complications and neurological deficits following minimally invasive anterior column release for adult spinal deformity: a retrospective study. Eur Spine J 24 (Suppl 3):397-404, 2015

53. Oliveira L, Marchi L, Coutinho E, Pimenta L: A radiographic assessment of the ability of the extreme lateral interbody fusion procedure to indirectly decompress the neural elements. Spine (Phila Pa 1976) 35 (26 Suppl):S331-S337, 2010

54. Ozgur BM, Aryan HE, Pimenta L, Taylor WR: Extreme Lateral Interbody Fusion (XLIF): a novel surgical technique for anterior lumbar interbody fusion. Spine J 6:435-443, 2006

55. Palumbo MA, Shah KN, Eberson CP, Hart RA, Daniels AH: Outrigger rod technique for supplemental support of posterior spinal arthrodesis. Spine J 15:1409-1414, 2015

56. Phan K, Rao PJ, Scherman DB, Dandie G, Mobbs RJ: Lateral lumbar interbody fusion for sagittal balance correction and spinal deformity. J Clin Neurosci 22:1714-1721, 2015

57. Phillips FM, Isaacs RE, Rodgers WB, Khajavi K, Tohmeh AG, Deviren V, et al: Adult degenerative scoliosis treated with XLIF: clinical and radiographical results of a prospective multicenter study with 24-month follow-up. Spine (Phila Pa 1976) 38:1853-1861, 2013

58. Pimenta L, Fortti F, Oliveira L, Marchi L, Jensen R, Coutinho E, et al: Anterior column realignment following lateral interbody fusion for sagittal deformity correction. Eur J Orthop Surg Traumatol 25 (Suppl 1):S29-S33, 2015

59. Rhee JM, Bridwell KH, Lenke LG, Baldus C, Blanke K, Edwards C, et al: Staged posterior surgery for severe adult spinal deformity. Spine (Phila Pa 1976) 28:2116-2121, 2003

60. Saigal R, Mundis GM Jr, Eastlack R, Uribe JS, Phillips FM, Akbarnia BA: Anterior column realignment (ACR) in adult 
sagittal deformity correction: technique and review of the literature. Spine (Phila Pa 1976) 41 (Suppl 8):S66-S73, 2016

61. Scheer JK, Tang JA, Deviren V, Buckley JM, Pekmezci M, McClellan RT, et al: Biomechanical analysis of revision strategies for rod fracture in pedicle subtraction osteotomy. Neurosurgery 69:164-172, 2011

62. Scheufler KM, Cyron D, Dohmen H, Eckardt A: Less invasive surgical correction of adult degenerative scoliosis, part I: technique and radiographic results. Neurosurgery 67:696710, 2010

63. Schwab F, Lafage V, Patel A, Farcy JP: Sagittal plane considerations and the pelvis in the adult patient. Spine (Phila Pa 1976) 34:1828-1833, 2009

64. Schwab F, Patel A, Ungar B, Farcy JP, Lafage V: Adult spinal deformity-postoperative standing imbalance: how much can you tolerate? An overview of key parameters in assessing alignment and planning corrective surgery. Spine (Phila Pa 1976) 35:2224-2231, 2010

65. Schwab F, Ungar B, Blondel B, Buchowski J, Coe J, Deinlein D, et al: Scoliosis Research Society-Schwab Adult Spinal Deformity Classification: a validation study. Spine (Phila Pa 1976) 37:1077-1082, 2012

66. Sciubba DM, Yurter A, Smith JS, Kelly MP, Scheer JK, Goodwin CR, et al: A comprehensive review of complication rates after surgery for adult deformity: a reference for informed consent. Spine Deform 3:575-594, 2015

67. Sethi RK, Pong RP, Leveque JC, Dean TC, Olivar SJ, Rupp SM: The Seattle Spine Team approach to adult deformity surgery: a systems-based approach to perioperative care and subsequent reduction in perioperative complication rates. Spine Deform 2:95-103, 2014

68. Sharma AK, Kepler CK, Girardi FP, Cammisa FP, Huang RC, Sama AA: Lateral lumbar interbody fusion: clinical and radiographic outcomes at 1 year: a preliminary report. J Spinal Disord Tech 24:242-250, 2011

69. Tempel ZJ, Gandhoke GS, Bonfield CM, Okonkwo DO, Kanter AS: Radiographic and clinical outcomes following combined lateral lumbar interbody fusion and posterior segmental stabilization in patients with adult degenerative scoliosis. Neurosurg Focus 36(5):E11, 2014

70. Tormenti MJ, Maserati MB, Bonfield CM, Okonkwo DO, Kanter AS: Complications and radiographic correction in adult scoliosis following combined transpsoas extreme lateral interbody fusion and posterior pedicle screw instrumentation. Neurosurg Focus 28(3):E7, 2010

71. Turner JD, Akbarnia BA, Eastlack RK, Bagheri R, Nguyen S, Pimenta L, et al: Radiographic outcomes of anterior column realignment for adult sagittal plane deformity: a multicenter analysis. Eur Spine J 24 (Suppl 3):427-432, 2015

72. Uribe JS, Deukmedjian AR, Mummaneni PV, Fu KM, Mundis GM Jr, Okonkwo DO, et al: Complications in adult spinal deformity surgery: an analysis of minimally invasive, hybrid, and open surgical techniques. Neurosurg Focus 36(5):E15, 2014

73. Uribe JS, Harris JE, Beckman JM, Turner AW, Mundis GM, Akbarnia BA: Finite element analysis of lordosis restoration with anterior longitudinal ligament release and lateral hyperlordotic cage placement. Eur Spine J 24 (Suppl 3):420-426, 2015

74. Uribe JS, Myhre SL, Youssef JA: Preservation or restoration of segmental and regional spinal lordosis using minimally invasive interbody fusion techniques in degenerative lumbar conditions: a literature review. Spine (Phila Pa 1976) 41 (Suppl 8):S50-S58, 2016

75. Uribe JS, Smith DA, Dakwar E, Baaj AA, Mundis GM, Turner AW, et al: Lordosis restoration after anterior longitudinal ligament release and placement of lateral hyperlordotic interbody cages during the minimally invasive lateral transpsoas approach: a radiographic study in cadavers. J Neurosurg Spine 17:476-485, 2012

76. Wang MY, Berven SH: Lumbar pedicle subtraction osteotomy. Neurosurgery 60 (2 Suppl 1):ONS140-ONS146, 2007

77. Wang MY, Mummaneni PV, Fu KM, Anand N, Okonkwo DO, Kanter AS, et al: Less invasive surgery for treating adult spinal deformities: ceiling effects for deformity correction with 3 different techniques. Neurosurg Focus 36(5):E12, 2014

78. Watkins RG IV, Hanna R, Chang D, Watkins RG III: Sagittal alignment after lumbar interbody fusion: comparing anterior, lateral, and transforaminal approaches. J Spinal Disord Tech 27:253-256, 2014

79. Wiggins GC, Ondra SL, Shaffrey CI: Management of iatrogenic flat-back syndrome. Neurosurg Focus 15(3):E8, 2003

80. Yagi M, Akilah KB, Boachie-Adjei O: Incidence, risk factors and classification of proximal junctional kyphosis: surgical outcomes review of adult idiopathic scoliosis. Spine (Phila Pa 1976) 36:E60-E68, 2011

81. Youssef JA, McAfee PC, Patty CA, Raley E, DeBauche S, Shucosky E, et al: Minimally invasive surgery: lateral approach interbody fusion: results and review. Spine (Phila Pa 1976) 35 (26 Suppl):S302-S311, 2010

\section{Disclosures}

Dr. Sethi reports consultant relationships with NuVasive and Orthofix and receipt of funding from K2M for a complex spine fellowship; the 2016-2017 fellow was Dr. Yanamadala.

\section{Author Contributions}

Conception and design: Leveque, Sethi. Acquisition of data: Leveque. Analysis and interpretation of data: Leveque, Yanamadala, Buchlak. Drafting the article: Leveque, Yanamadala, Sethi. Critically revising the article: Yanamadala, Buchlak, Sethi. Reviewed submitted version of manuscript: Yanamadala, Buchlak, Sethi. Approved the final version of the manuscript on behalf of all authors: Leveque. Administrative/technical/material support: Leveque, Sethi.

\section{Supplemental Information}

\section{Previous Presentations}

Portions of this work were presented in abstract form at the ninth annual research meeting of the Society for Lateral Access Surgery, Carlsbad, CA, March 10-12, 2016.

\section{Correspondence}

Jean-Christophe Leveque, Neuroscience Institute, Virginia Mason Medical Center, 1100 Ninth Ave., Seattle, WA 98101. email: jean-christophe.leveque@virginiamason.org. 